\title{
Testing for $N$-methyl-D-aspartate Receptor Autoantibodies in Clinical Practice
}

\author{
John Brooks@, Melanie L. Yarbrough, Robert C. Bucelli, Gregory S. Day®
}

\begin{abstract}
Background: The diagnosis of anti- $N$-methyl-D-aspartate receptor (NMDAR) encephalitis relies on the detection of NMDAR IgG autoantibodies in the serum or cerebrospinal fluid (CSF) of symptomatic patients. Commercial kits are available that allow NMDAR IgG autoantibodies to be measured in local laboratories. However, the performance of these tests outside of reference laboratories is unknown. Objectives: To report an unexpectedly low rate of NMDAR autoantibody detection in serum from patients with anti-NMDAR encephalitis tested using a commercially available diagnostic kit in an exemplar clinical laboratory. Methods: Paired CSF and serum samples from seven patients with definite anti-NMDAR encephalitis were tested for NMDAR IgG autoantibodies using commercially available cell-based assays run according to manufacturer's recommendations. Rates of autoantibody detection in serum tested at our center were compared with those derived from systematic review and meta-analyses incorporating studies published during or before March 2019. Results: NMDAR IgG autoantibodies were detected in the CSF of all patients tested at our clinical laboratory but not in paired serum samples. Rates of the detection were lower than those previously reported. A similar association was recognized through meta-analyses, with lower odds of NMDAR IgG autoantibody detection associated with serum testing performed in nonreference laboratories. Conclusions: Commercial kits may yield lower-than-expected rates of NMDAR $\mathrm{IgG}$ autoantibody detection in serum when run in exemplar clinical (nonreference) laboratories. Additional studies are needed to decipher the factors that contribute to lower-than-expected rates of serum positivity. CSF testing is recommended in patients with suspected anti-NMDAR encephalitis.
\end{abstract}

RÉSUMÉ: Effectuer en pratique clinique des tests visant à mesurer les anticorps anti-récepteurs NMDA. Contexte: Le diagnostic de l'encéphalite limbique avec anticorps anti-récepteurs NMDA repose sur la détection d'autoanticorps de classe IgG dans le sérum ou le liquide céphalo-rachidien des patients symptomatiques. Il existe certes des trousses commerciales qui permettent de mesurer ces autoanticorps dans des laboratoires locaux. Cependant, l'efficacité de ces tests en dehors de laboratoires homologués demeure inconnue. Objectif: Signaler un taux d'autoanticorps étonnamment faible dans le sérum de patients atteints d'encéphalite limbique avec anticorps anti-récepteurs NMDA, et ce, au moyen d'une trousse diagnostique commerciale utilisée dans un laboratoire clinique de haut niveau. Méthodes: En suivant les recommandations d'un fabricant, nous avons testé les échantillons appariés de liquide céphalo-rachidien et de sérum de sept patients atteints d'encéphalite limbique avec anticorps anti-récepteurs NMDA. À l'aide d'un bio-essai cellulaire, l'objectif était alors de détecter dans notre centre des autoanticorps de classe IgG et de comparer nos résultats à ceux obtenus à la suite d'une synthèse systématique et de méta-analyses incluant des études publiées au cours du mois de mars 2019 ou avant cette période. Résultats:Des autoanticorps de classe IgG en lien avec des anticorps anti-récepteurs NMDA ont été détectés dans le liquide céphalo-rachidien de tous les patients qui ont fait l'objet d'un test dans notre laboratoire clinique mais non pas dans les échantillons de sérum appariés. Les taux de détection se sont révélés plus faibles que ceux signalés précédemment. Nous avons observé une association similaire lors de méta-analyses, la probabilité de détecter des autoanticorps de classe IgG en lien avec des anticorps anti-récepteurs NMDA étant plus faible lorsqu'associée à des tests de sérum réalisés dans des laboratoires non homologués. Conclusions: Il est donc possible que les trousses commerciales ne débouchent sur des taux de détection d'autoanticorps de classe IgG plus faibles dans les sérums lorsqu'elles sont utilisées dans des laboratoires cliniques de haut niveau qui ne sont pas homologués. Des études complémentaires sont nécessaires pour mieux comprendre les facteurs qui contribuent à ces taux de positivité sérique plus bas que prévus. Enfin, des tests du liquide céphalo-rachidien sont recommandés chez des patients dont on soupçonne qu'ils sont atteints d'encéphalite limbique avec anticorps antirécepteurs NMDA.

Keywords: Anti-NMDA receptor encephalitis, Autoimmune encephalitis, Diagnostic testing doi: $10.1017 / \operatorname{cjn} .2019 .305$

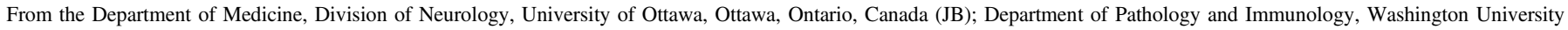
School of Medicine, Saint Louis, MO, USA (MLY); Department of Neurology, Washington University School of Medicine, Saint Louis, MO, USA (RCB, GSD)

Received June 2, 2019. Final Revisions Submitted September 17, 2019. Date of Acceptance September 24, 2019.

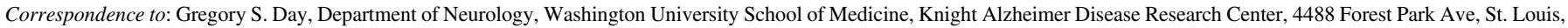
MO 63108, USA. Email: gday@wustl.edu 


\section{INTRODUCTION}

Since its description in $2007,{ }^{1}$ anti- $N$-methyl-D-aspartate receptor (NMDAR) encephalitis is increasingly recognized as a common, potentially reversible cause of psychiatric and neurologic morbidity. ${ }^{2}$ Early diagnosis and treatment is key to optimizing outcomes, ${ }^{3,4}$ exemplifying the need for rapid and reliable antibody testing in patients with suspected antiNMDAR encephalitis. The detection of $\operatorname{IgG}$ autoantibodies against the GluN1 subunit of central nervous system NMDARs establishes the diagnosis in symptomatic patients. ${ }^{5,6}$ Although cerebrospinal fluid (CSF) testing remains the gold standard (with sensitivity approaching $100 \%$ ), a prior study evaluating large numbers of samples at a single center identified NMDAR IgG autoantibodies in the serum of more than $80 \%$ of affected patients. ${ }^{7}$ These findings, if replicated in exemplar clinical environments, could be used to rationalize serum screening in patient populations and clinical settings where CSF collection is challenging, impractical, or inconvenient, including pediatric populations, ${ }^{8}$ mental health settings, ${ }^{9}$ and outpatient clinics.

In response to the growing demand for autoantibody testing, hospital-based laboratories have begun to test for diseaseassociated autoantibodies utilizing commercially available kits. Although in-house testing offers some compelling advantages, namely reduced cost and turnaround time, the performance characteristics of these tests in newly diagnosed patients assessed in exemplar clinical environments are unknown. It is imperative that neurologists appreciate the applications and limitations of autoantibody tests used to support or refute a clinical diagnosis, particularly as access to antibody testing continues to expand. Recognizing this, we reviewed the results of serum NMDAR IgG autoantibody testing in consecutively accrued patients with anti-NMDAR encephalitis assessed at our tertiary care center. Testing was completed on serum samples drawn at the time of antibody detection in the CSF, using commercially available cell-based assays run in accordance with the manufacturer's specifications. Local results were compared with those derived from systematic review and meta-analysis incorporating published reports providing data concerning the results of serum NMDAR IgG autoantibody testing in patients with definite anti-NMDAR encephalitis. The potential influence of the laboratory setting and method of testing on serum NMDAR IgG autoantibody detection was considered via subanalyses of reported data.

\section{Methods}

\section{Protocol Approvals, Registrations, and Patient Consent}

Eleven patients were diagnosed with anti-NMDAR encephalitis at Barnes-Jewish Hospital (BJH; Washington University School of Medicine, Saint Louis, MO, USA) from January 2012 to December 2017. All patients were enrolled in prospective observational research studies permitting longitudinal clinical evaluation and banking of CSF. Patients met clinical criteria for definite anti-NMDAR encephalitis, ${ }^{5}$ with clinical phenotypes consistent with proposed diagnostic criteria (patients presenting with at least one of agitation/psychosis, dyskinesia, decreased level of consciousness, speech dysfunction, seizure or dysautonomia, and anti-NMDAR IgG autoantibodies identified in the CSF). Study protocols were approved by the Washington
University School of Medicine Human Research Protection Office. Patients or their delegates provided written informed consent prior to participation.

\section{Autoantibody Testing}

Testing for NMDAR IgG autoantibodies was performed by trained laboratory personnel at $\mathrm{BJH}$ using the commercially available EUROIMMUN Anti-Glutamate Receptor (type NMDA) immunofluorescence kit (catalog \#:FA112d-1005-51) - a cellbased assay with fixed cells. CSF samples were used undiluted, while serum samples were diluted 1:10. All testing was performed in accordance with the manufacturer's instructions. ${ }^{10}$ The quoted sensitivity and specificity of the kits for the detection of NMDAR IgG autoantibodies, derived principally from serum testing, are $98.1 \%(89.7 \%-100 \%)$ and $100 \%(97.2 \%-100 \%)$, respectively. ${ }^{10}$

\section{Literature Review}

We systematically appraised the literature to determine the prevalence of "positive" serum testing for NMDAR IgG autoantibodies in patients with definite anti-NMDAR encephalitis (Figure 1). The search was conducted using the PubMed and Embase databases with the following search expression: (CSF AND SERUM) AND (NMDA OR NMDARE OR NMDAR OR anti-NMDA OR anti-NMDAR OR antiNMDARE OR $N$-methyl-D-aspartate OR $N$-methyl-D-aspartate receptor encephalitis OR anti- $N$-methyl-D-aspartate receptor encephalitis OR NMDAR encephalitis OR Anti-NMDAR encephalitis). Articles and abstracts published on or before March 30, 2019 were included regardless of the original language of publication. All relevant works were independently reviewed by two study authors (JAB and GSD), and clinical data were extracted concerning CSF and serum autoantibody positivity and presenting symptoms and signs. Eleven articles included cases where paired CSF and serum antibody tests were available from some cases but not others. In these instances, only results from paired CSF and serum samples were included in the analyses. Several articles reported findings from the same source population. In these cases, results from the most recent publication were reported. ${ }^{4,7,11}$ Studies with individual confidence interval estimates that fell outside the pooled confidence interval of the subgroup were identified as outliers, and were excluded from meta-analyses. Individuals with CSF testing negative for NMDAR IgG autoantibodies were assumed to be suffering from a form of autoimmune encephalitis other than anti-NMDAR encephalitis, and were excluded from analyses. Studies meeting inclusion criteria were pooled using a random effects model.

The laboratory setting and methods used to evaluate NMDAR IgG autoantibodies were extracted from published reports or, when not explicitly stated, from correspondence with study authors. Laboratory setting was defined as local/regional or reference/research (i.e., laboratories actively supporting research into anti-NMDAR encephalitis). To be defined as a research laboratory, the testing institution was required to be ranked in the top half of rankings listed in the SCImago institutional ratings for health research (271 rankings assigned as derived from the Scopus database). ${ }^{12}$ Granular data concerning preanalytic variables (e.g., serum collection protocols, specimen handling and storage, and dilution) were not routinely 


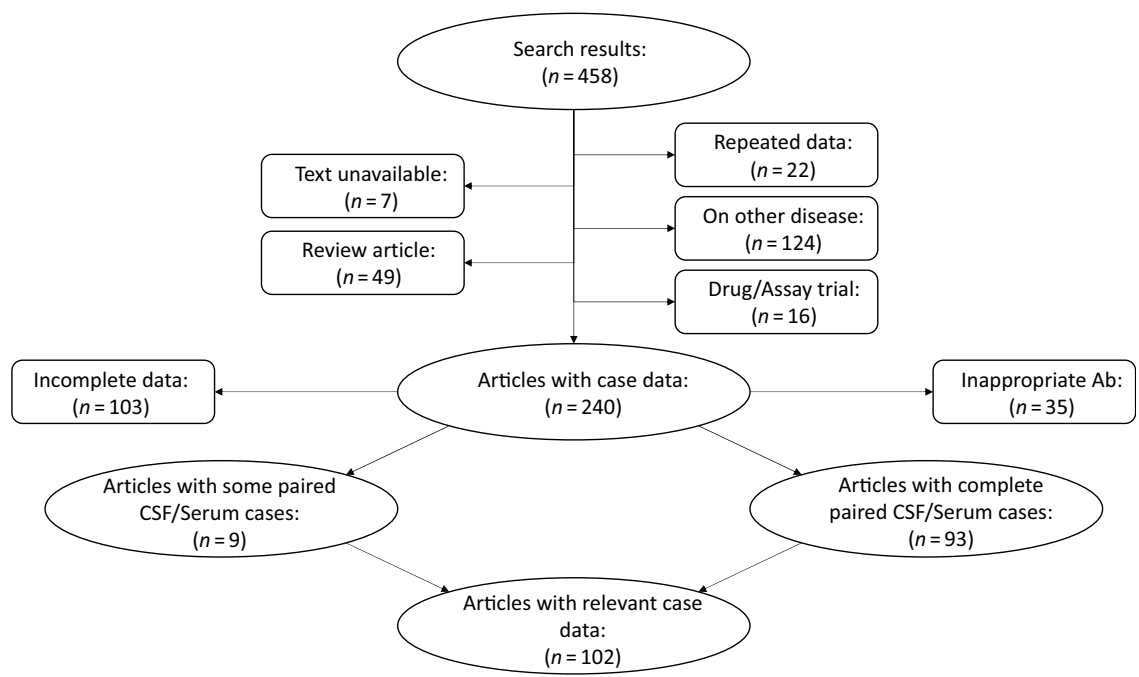

Figure 1: Flow diagram depicting results of the meta-analysis. See methods for search terms. Search results were reviewed and articles excluded if they focused on animal studies, diseases other than anti-NMDAR encephalitis, drug treatment without patient data, or if the article was unavailable for review or was a reference article (no patient data). Articles were also excluded if paired CSF and serum antibody test results were not reported, or if antibodies other than NMDAR IgG autoantibodies were reported. Relevant data were extracted from the 108 resultant articles and used to inform results. Ab=antibody; CSF = cerebrospinal fluid.

reported or collected. Testing approaches were defined as multimodal (e.g., evaluation with immunohistochemistry followed by cell-based assay) or unimodal (e.g., use of cell-based assay alone). Complete data were available from 17/102 (17\%) published studies, which accounted for $432 / 612(71 \%)$ of the total number of patients sampled. The association between test site (local/regional vs. reference/research) and modality (multimodal/unimodal), and odds of serum NMDAR IgG autoantibody detection were measured with two-factor regression, incorporating studies with complete datasets.

No formal bias assessment was performed given that the majority of included studies were retrospective case studies or case series, and therefore subject to a high degree of bias (Level III or IV evidence according to the American Academy of Neurology Classification of Evidence Matrices for diagnostic or prognostic questions ${ }^{13}$ ). An unweighted Cohen's Kappa was computed, reflecting the overall agreement between raters with regard to a trichotomous selection of inclusion, partial inclusion, and exclusion of studies.

\section{Statistical Analysis}

Data were analyzed using R version 3.6.0 (The R Foundation, Vienna, Austria). Continuous and categorical measures were compared using the Mann-Whitney $U$-test and Fisher's exact test, respectively. Statistical significance was defined as $p<0.05$, except for measures of heterogeneity where statistical significance was defined as $p<0.10$. Confidence intervals for concordance of the detection of NMDAR IgG autoantibodies in serum versus CSF were computed using a Clopper-Pearson exact technique. Inconsistency across studies was computed using established methods. ${ }^{14,15}$ Pooled effects were computed using a random effects model given the apparent effect-related heterogeneity initially on inspection of the data. A McNemar test was used to compare autoantibody detection by testing using two differing techniques in the established literature.

\section{Results}

Table 1 summarizes the demographic features, details of the clinical presentation and disease course, and results of NMDAR IgG autoantibody testing in the 11 patients evaluated at our center. The median age-at-symptom onset of anti-NMDAR encephalitis was 23 years (range, 15-52). The median time from first-reported symptom (or first symptom indicating relapse in one patient) to NMDAR autoantibody testing was 28 days (range, $11-219 ; n=11$ ) in CSF and 30 days (range, $10-218 ; n=7$ ) in serum. In general, disease-defining symptoms and signs emerged in an ordered pattern (Figure 2), with 10/11 (91\%) patients fulfilling clinical criteria for "probable anti-NMDAR encephalitis" within a median of 19 days (range, 9-60) from the onset of first symptoms. The remaining patient (patient 9) presented with agitation/ psychosis, decreased consciousness, and seizures at the peak of his illness (day 31), satisfying three of six proposed clinical criteria for the diagnosis of anti-NMDAR encephalitis. ${ }^{5}$

NMDAR IgG autoantibodies were detected within the CSF of all patients, establishing the diagnosis of definite antiNMDAR encephalitis. ${ }^{5}$ Paired serum samples were available from 7/11 (64\%) patients at the time of presentation. No clinically meaningful differences were observed between patients with $(n=7)$ and without paired serum samples $(n=4)$ concerning median age (28 years [18-52] vs. 21.5 years $[15-35] ; p=0.51)$, the proportion of females (0.71 vs. 0.50 ; $p=0.80$ ), or the median time from symptom onset to the detection of NMDAR IgG autoantibodies in the CSF (24 days [11-219] vs. 29.5 days [17-57]; $p=0.78$ ). NMDAR autoantibodies were not detected within the serum of any patient $(0 / 6)$ tested at our center. A third case (Case 5) was tested exclusively at a high-volume reference laboratory (Mayo Clinic, Rochester, MN, USA); NMDAR IgG autoantibodies were similarly detected only in CSF (0/7 positive in paired serum samples).

Findings from our patients were compared with those from 102 publications reporting results of autoantibody testing in 
Table 1: Demographic features, details of clinical presentation and course, and results of diagnostic testing for 11 anti-NMDAR encephalitis patients evaluated at our center

\begin{tabular}{|c|c|c|c|c|c|c|c|c|}
\hline \multirow{3}{*}{ Case } & \multirow{3}{*}{ Age, M/F } & \multirow{3}{*}{ Symptoms/Signs } & \multicolumn{4}{|c|}{ NMDAR IgG antibody test results } & \multirow{3}{*}{ Additional diagnostic testing } & \multirow{3}{*}{ Treatment } \\
\hline & & & \multicolumn{2}{|c|}{ In-house } & \multicolumn{2}{|c|}{ Reference } & & \\
\hline & & & CSF & Serum & CSF & Serum & & \\
\hline 1 & $20 \mathrm{~F}$ & $\begin{array}{l}\text { 1. A/P, Sz } \\
\text { 2. Dk, Da }\end{array}$ & $\begin{array}{c}+ \\
(\text { Day } 57)\end{array}$ & NA & $\begin{array}{c}+ \\
(\text { Day } 57)\end{array}$ & NA & $\begin{array}{l}\text { EEG: AC } \\
\text { MRI brain: ANS } \\
\text { Tumor: none }\end{array}$ & $\begin{array}{l}\text { Oral steroids, IVMP, IVIg, } \\
\text { PLEX, rituximab }\end{array}$ \\
\hline 2 & $23 \mathrm{~F}$ & $\begin{array}{l}\text { 1. } \mathrm{A} / \mathrm{P} \\
\text { 2. SD } \\
\text { 3. LOC, Dk, Da }\end{array}$ & $\begin{array}{c}+ \\
(\text { Day } 32)\end{array}$ & $\begin{array}{c}- \\
(\text { Day } 30)\end{array}$ & $\begin{array}{c}+ \\
(\text { Day } 32)\end{array}$ & NA & $\begin{array}{l}\text { EEG: AC } \\
\text { MRI brain: Nm } \\
\text { Tumor: Mature ovarian teratoma }\end{array}$ & IVMP, IVIg, PLEX \\
\hline 3 & $35 \mathrm{~F}$ & $\begin{array}{l}\text { 1. LOC, SD } \\
\text { 2. A/P } \\
\text { 3. Da }\end{array}$ & $\begin{array}{c}+ \\
(\text { Day } 31)\end{array}$ & NA & $\begin{array}{c}+ \\
(\text { Day } 31)\end{array}$ & NA & $\begin{array}{l}\text { EEG: ANS } \\
\text { MRI brain: Nm } \\
\text { Tumor: none }\end{array}$ & IVMP, IVIg \\
\hline 4 & $31 \mathrm{M}$ & $\begin{array}{l}\text { 1. LOC, } \mathrm{Sz} \\
\text { 2. A/P 3. Da }\end{array}$ & NA & $\begin{array}{c}- \\
\text { (Day 32) }\end{array}$ & $\begin{array}{c}+ \\
(\text { Day } 24)\end{array}$ & $\begin{array}{c}- \\
\text { (Day 32) }\end{array}$ & $\begin{array}{l}\text { EEG: ANS } \\
\text { MRI brain: Nm } \\
\text { Tumor: none }\end{array}$ & IVMP, PLEX, IVIg \\
\hline 5 & $18 \mathrm{~F}$ & $\begin{array}{l}\text { 1. } \mathrm{A} / \mathrm{P} \\
\text { 2. LOC, Dk, Da }\end{array}$ & NA & NA & $\begin{array}{c}+ \\
(\text { Day } 23)\end{array}$ & $\begin{array}{c}- \\
\text { (Day 23) }\end{array}$ & $\begin{array}{l}\text { EEG: ANS } \\
\text { MRI brain: Nm } \\
\text { Tumor: none }\end{array}$ & $\begin{array}{l}\text { IVMP, PLEX, } \\
\text { rituximab }\end{array}$ \\
\hline 6 & $15 \mathrm{M}$ & \begin{tabular}{|l|} 
1. SD \\
2. LOC \\
3. A/P, Dk \\
\end{tabular} & NA & NA & $\begin{array}{c}+ \\
(\text { Day } 28)\end{array}$ & NA & $\begin{array}{l}\text { EEG: } \mathrm{Nm} \\
\text { MRI rain: Nm } \\
\text { Tumor: none }\end{array}$ & IVMP \\
\hline 7 & $20 \mathrm{M}$ & $\begin{array}{l}\text { 1. } \mathrm{Dk} \\
\text { 2. SD, A/P, Sz }\end{array}$ & NA & $\begin{array}{c}- \\
(\text { Day } 10)\end{array}$ & $\begin{array}{c}+ \\
(\text { Day } 11)\end{array}$ & $\begin{array}{c}- \\
(\text { Day } 10)\end{array}$ & $\begin{array}{l}\text { EEG: ANS } \\
\text { MRI brain: ANS } \\
\text { Tumor: none }\end{array}$ & IVMP, IVIg \\
\hline 8 & $32 \mathrm{~F}$ & $\begin{array}{l}\text { 1. } \mathrm{A} / \mathrm{P} \\
\text { 2. } \mathrm{Dk} \\
\text { 3. LOC } \\
\text { 4. SD, Sz, Da }\end{array}$ & $\begin{array}{c}+ \\
(\text { Day } 32)\end{array}$ & $\begin{array}{c}- \\
(\text { Day } 31)\end{array}$ & NA & NA & $\begin{array}{l}\text { EEG: ANS } \\
\text { MRI brain: Nm } \\
\text { Tumor: none }\end{array}$ & $\begin{array}{l}\text { IVMP, IVIg, PLEX, } \\
\text { rituximab }\end{array}$ \\
\hline 9 & $23 \mathrm{M}$ & $\begin{array}{l}\text { 1. } \mathrm{A} / \mathrm{P}, \mathrm{LOC} \\
\text { 2. } \mathrm{Sz}\end{array}$ & NA & NA & $\begin{array}{c}+ \\
(\text { Day 17) }\end{array}$ & NA & $\begin{array}{l}\text { EEG: ANS } \\
\text { MRI brain: AC } \\
\text { Tumor: none }\end{array}$ & IVMP, IVIg, rituximab \\
\hline 10 & $52 \mathrm{~F}$ & \begin{tabular}{|l|} 
1. SD \\
2. LOC \\
3. A/P \\
4. Dk \\
5. Sz \\
\end{tabular} & $\begin{array}{c}+ \\
(\text { Day 219) }\end{array}$ & $\begin{array}{c}- \\
(\text { Day } 218)\end{array}$ & $\begin{array}{c}+ \\
(\text { Day 219) }\end{array}$ & NA & $\begin{array}{l}\text { EEG: ANS } \\
\text { MRI brain: ANS } \\
\text { Tumor: none }\end{array}$ & Oral steroid, IVMP, IVIg \\
\hline 11 & $28 \mathrm{~F}$ & $\begin{array}{l}\text { 1. } \mathrm{Sz}, \mathrm{Da} \\
\text { 2. } \mathrm{SD}, \mathrm{A} / \mathrm{P} \\
\text { 3. } \mathrm{Dk}, \mathrm{LOC}\end{array}$ & $\begin{array}{c}+ \\
(\text { Day 13) }\end{array}$ & $\begin{array}{c}- \\
(\text { Day } 11)\end{array}$ & NA & NA & $\begin{array}{l}\text { EEG: AC } \\
\text { MRI: Nm } \\
\text { Tumor: none }\end{array}$ & IVMP, PLEX, rituximab \\
\hline
\end{tabular}

Symptoms are ordered by onset. Timing of CSF and serum testing is presented relative to the day of symptom onset. MRI and EEG findings were either normal (Nm: indicating no pathological abnormality), abnormal-nonspecific (ANS: indicating abnormalities that are not specific for anti-NMDAR encephalitis, including nonspecific FLAIR signal changes on MRI, and slowing on EEG) or abnormal-consistent (AC: indicating abnormalities that are consistent with anti-NMDAR encephalitis, such as mesial temporal lobe signal changes with or without extension into adjacent limbic structures on MRI, and delta-brush on EEG). No adverse events were attributed to blood draw or lumbar puncture. + = Positive result; $-=\mathrm{Negative} \mathrm{result;} \mathrm{A/P} \mathrm{=} \mathrm{Agitation/}$ Psychosis; $\mathrm{CSF}=$ Cerebrospinal fluid; $\mathrm{Da}=$ Dysautonomia; Dk = Dyskinesia; EEG = Electroencephalogram; FLAIR $=\mathrm{T} 2$-fluid-attenuated inversion recovery; $\mathrm{LOC}=$ Altered level of consciousness; MRI = Magnetic resonance image; IVMP = Intravenous methylprednisolone; IVIg $=$ Intravenous immunoglobulin; PLEX = Plasmapheresis/plasma exchange; $\mathrm{SD}=$ Speech dysfunction; $\mathrm{Sz}=$ Seizure .

CSF and serum from 663 patients who met criteria for definite anti-NMDAR encephalitis (i.e., all patients had clinical presentations consistent with anti-NMDAR encephalitis with NMDAR IgG autoantibodies detected in CSF; Supplemental Appendix 1). Inter-rater reliability was high (GSD and JAB, $\kappa=0.95$ ). Disagreement arose over five cases considered by the reviewers to have anti-NMDAR encephalitis that had positive autoantibodies in the serum but not in CSF. ${ }^{16-18}$ Ultimately, consensus was reached to exclude these cases as absence of intrathecal NMDAR IgG autoantibodies was taken to suggest another antibody-mediated or other cause of the clinical presentation (e.g., limbic encephalitis, refractory seizure, etc.).

Serum NMDAR IgG autoantibody detection was $92 \%$ (95\%CI: 88\%-95\%) that of CSF with the full dataset $(n=612)$ and $82 \%(95 \% \mathrm{CI}: 71 \%-92 \%)$ in the dataset limited to studies with complete information $(n=432$; Table 2, Figure 3). (The present study was excluded from this analysis as it was determined to be an outlier.) Substantial heterogeneity was 
Table 2: Results of literature review including cases with definite anti-NMDAR encephalitis for whom complete data concerning the results of autoantibody testing in serum and CSF were available

\begin{tabular}{|c|c|c|c|c|c|}
\hline \multirow{2}{*}{ Reference } & \multirow{2}{*}{$\begin{array}{c}\text { Patients with paired } \\
\text { samples (n) }\end{array}$} & \multirow{2}{*}{ Age (median [range]) } & \multirow{2}{*}{ M:F } & \multicolumn{2}{|c|}{ NMDAR antibody testing } \\
\hline & & & & Serum +: CSF + & Technique/Test site \\
\hline Gresa-Arribas et al. $^{7}$ & 250 & Unknown & Unknown & $232: 250$ & $2 / \mathrm{R}$ \\
\hline Wang et al. ${ }^{19}$ & 43 & 23 [9-39] & $19: 24$ & $27: 43$ & $1 / \mathrm{L}$ \\
\hline Saito et al. ${ }^{20}$ & 37 & Unknown & Unknown & $17: 37$ & $1 / \mathrm{L}$ \\
\hline Aungsumart et al. ${ }^{21}$ & 31 & 19 [IQR: 15-31] & $12: 19$ & $21: 31$ & $2 / \mathrm{L}$ \\
\hline Ding et al. ${ }^{22}$ & 24 & Mean: 40 (SD: 18) & $10: 14$ & $18: 24$ & $1 / \mathrm{L}$ \\
\hline Maat et al. ${ }^{16}$ & $12: 15$ & $25[5-56]$ & $2: 13$ & $9: 12(0)$ & $1 / \mathrm{R}$ \\
\hline Mahadevan et al. ${ }^{23}$ & 11 & Unknown & Unknown & $11: 11$ & $1 / \mathrm{L}$ \\
\hline Suhs et al. ${ }^{17}$ & $5: 7$ & [23-57] & $0: 7$ & $4: 5(1)$ & $1 / \mathrm{L}$ \\
\hline Kataoka et al. ${ }^{24}$ & 3 & $29[18-46]$ & $1: 2$ & $3: 3$ & $2 / \mathrm{R}$ \\
\hline Gastaldi et al. ${ }^{25}$ & $3: 5$ & Unknown & Unknown & $3: 3$ & $2 / \mathrm{R}$ \\
\hline Zandi et al. ${ }^{26}$ & $5: 8$ & Unknown & Unknown & $5: 5(3)$ & $2 / \mathrm{R}$ \\
\hline Alexopoulos et al. ${ }^{27}$ & $5: 5$ & 29 [9 months, 58] & $0: 3$ & $3: 3$ & $1 / \mathrm{L}$ \\
\hline Barros et al. ${ }^{28}$ & 1 & 7 & 1:0 & $1: 1$ & $2 / R$ \\
\hline Fauzi et al. ${ }^{29}$ & 1 & 21 & $0: 1$ & $1: 1$ & $1 / \mathrm{L}$ \\
\hline Zhou et al. ${ }^{30}$ & 1 & 54 & 1:0 & $1: 1$ & $1 / \mathrm{R}$ \\
\hline Orengo et al. ${ }^{31}$ & 1 & 29 & $0: 1$ & $0: 1$ & $1 / \mathrm{R}$ \\
\hline Guan et al. ${ }^{32}$ & 1 & 59 & $0: 1$ & $1: 1$ & $1 / \mathrm{L}$ \\
\hline
\end{tabular}

When relevant, the " $n$ " for patients with paired samples indicates both the number of patients with paired CSF and serum samples (numerator), as a proportion of the total cases presented (denominator). The NMDAR autoantibody testing reports number of serum positive (numerator) compared to number of CSF positive (denominator) results. The number of patients who demonstrated positivity in serum but not CSF is included in parentheses (excluded from analyses). The median age and age range of patients presented in each study are listed unless otherwise stated. Time between CSF and serum testing, and severity of illness were not uniformly reported. No adverse events were reported secondary to blood draw or lumbar puncture. $1=$ Single modality testing; $2=$ Multimodal testing $(\geq 2$ modalities used); CSF $=$ Cerebrospinal fluid; $\mathrm{L}=$ Testing performed at local/regional test site; $\mathrm{R}=$ Testing performed at reference/research test site.

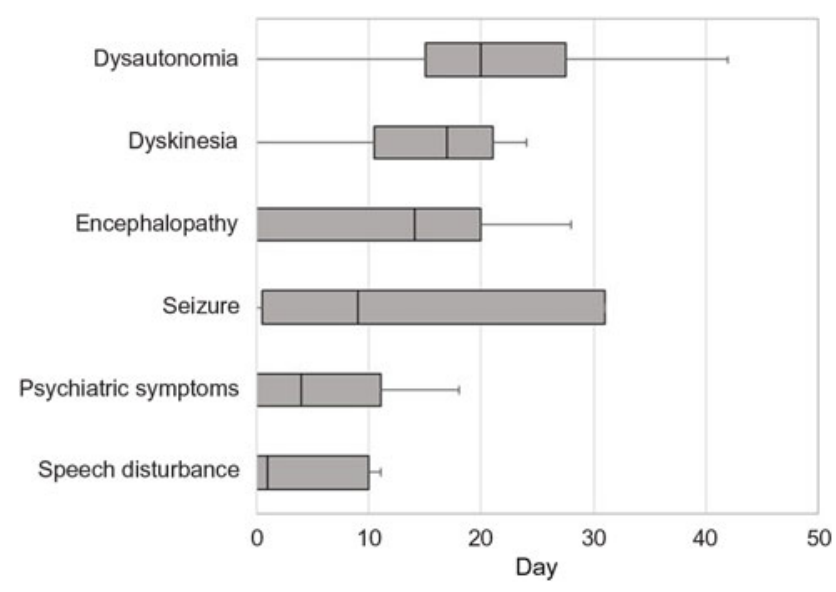

Figure 2: Box plot depicting the median number of days from the onset of first symptom(s) to the emergence of symptoms and signs typical of anti-NMDAR encephalitis.

observed in data from the local/regional laboratory subgroup; mild-to-moderate heterogeneity was observed in data from the reference/research laboratory group. Two-factor regression analyses established reduced odds of serum NMDAR IgG autoantibody detection when serum was tested using an unimodal approach (e.g., cell-based assay without additional technique; $\mathrm{OR}=0.20 ; 95 \% \mathrm{CI}$ : $0.04-0.94 ; p=0.04$ ) and when testing was performed within local/regional laboratories $(\mathrm{OR}=0.20$; 95\%CI: $0.05-0.81 ; p=0.02)$.

\section{Discussion}

NMDAR IgG autoantibodies were detected in the CSF of all 11 patients with anti-NMDAR encephalitis assessed at our center but not in paired serum samples tested in 7 patients. Rates of serum detection $(0 / 7)$ were lower-than-reported in the relevant literature. The use of a single test for antibodies and testing with local/regional laboratories were associated with reduced odds of NMDAR IgG autoantibody detection in serum in published cases. These findings raise important questions concerning the influence of testing methodology and location on rates of serum NMDAR IgG autoantibody detection in patients with definite anti-NMDAR encephalitis.

The lower-than-expected rate of serum NMDAR IgG autoantibody detection at our center may reflect the small sample size and differences in our patient population compared to prior published studies. Indeed, only one patient in our sample had a 


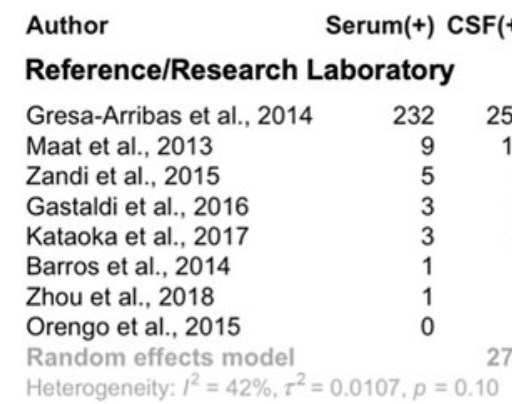

Regional/Local Laboratory

Wang et al., 2015

Saito et al., 2017

Aungsumart et al., 2018

Ding et al., 2018

Mahadevan et al., 2016

Suhs et al., 2015

Alexopoulos et al., 2018

Guan et al., 2015

Fauzi et al., 2017

Random effects model

Heterogeneity: $I^{2}=79 \%, \tau^{2}=0.0376, p<0.01$

\section{Random effects model}

Heterogeneity: $I^{2}=77 \%, \tau^{2}=0.0258, p<0.01$

Residual heterogeneity: $I^{2}=70 \%, p<0.01$
Proportion $\quad 95 \%-\mathrm{Cl}$ Weight

Figure 3: Forest plot with estimates of serum concordance with cerebrospinal fluid testing (diamonds) for NMDAR autoantibodies and 95\% confidence intervals (solid bars), ordered by descending sample size. Studies with a sample size $<5$ where the testing performed was not stated are not displayed.

disease-associated ovarian teratoma - a commonly associated neoplasm that may associate with higher serum NMDAR IgG autoantibody titers. ${ }^{7}$ Alternatively, differences may be attributed to variation in performance and interpretation of test results across centers - a hypothesis supported by the high level of heterogeneity in serum/CSF test concordance observed across studies included in the meta-analysis, and by the observation that the laboratory environment and modality of testing (multimodal vs. unimodal) influenced rates of serum autoantibody detection.

Additional factors may contribute to lower rates of serum antibody detection at clinical centers like our own, including differences in the initial sample collection (e.g., timing of collection, equipment used for collection), handling and processing (e.g., sample dilution, interval between sampling and testing, freeze/thaw cycles), testing, and interpretation of test results. In addition, academic and reference laboratories may adopt laboratory-specific practices intended to enhance assay performance, including the use of secondary or tertiary diagnostic tests (e.g., brain immunohistochemistry, live cell-based assays) to increased diagnostic accuracy. ${ }^{7,11,33}$ Indeed, the landmark study by Gresa-Arribas et al. suggested improved rates of NMDAR IgG autoantibody detection when serum was tested using rat brain immunohistochemistry in addition to cell-based assays with fixed or live NMDAR-expressing cells. ${ }^{7}$ Although effective, these solutions increase the costs and complexity of testing, detracting from the perceived advantages of in-house testing using commercially available tests marketed for this purpose. Such solutions may be particularly challenging to implement within lower throughput laboratories, where the appeal of one-step commercial testing may be greatest. These possibilities warrant further evaluation through a well-designed systematic study considering the effects of experimental variation in sample collection, handling and processing, testing, and interpretation of test results on serum antibody detection.

Deciphering the factors that influence rates of NMDAR IgG autoantibody detection in serum has important implications for research and clinical care. Anti-NMDAR encephalitis is a potentially treatable cause of first-episode psychoses, ${ }^{34}$ postpartum psychoses, ${ }^{35,36}$ refractory mood disorders, ${ }^{37}$ unexplained behavioral changes, ${ }^{38-40}$ and neuroleptic sensitivity. ${ }^{41,42}$ Accordingly, screening for serum NMDAR IgG autoantibodies has been performed in individuals with unexplained psychiatric presentations in whom obtaining CSF may present undue challenges. ${ }^{2,9,34}$ However, building evidence suggests that the accuracy of serum testing alone is inadequate. ${ }^{7}$ Indeed, at least 1 of 13 patients with definite anti-NMDAR encephalitis included in our meta-analyses may have been misdiagnosed if relying on serum testing alone. This clinical practice point is even more relevant when evaluating patients with atypical clinical presentations (e.g., patients with first-episode psychoses), in whom the identification of NMDAR $\operatorname{IgG}$ autoantibodies in serum alone may fail to inform the clinical diagnoses. ${ }^{9}$ Taken together, these findings reinforce the need to test for NMDAR IgG autoantibodies in the CSF of patients with suspected anti-NMDAR encephalitis.

Several barriers may impede CSF testing in patients with prominent psychiatric signs, including the need to obtain informed consent in decisionally impaired patients, and practical challenges associated with performing a diagnostic lumbar puncture outside of traditional inpatient settings. It is important to circumvent these barriers to ensure the most accurate evaluation and to deliver the best possible care to at-risk patients. This 
may necessitate further collaboration between neurological and psychiatric service providers in outpatient and inpatient settings. On the neurology service, where diagnostic lumbar punctures are routine and can be safely performed with minimal pain or risk to the patient, simultaneous screening of CSF and serum samples for disease-associated autoantibodies is recommended in patients with suspected autoimmune encephalitis to promote early detection of disease-associated autoantibodies. This strategy allows for early treatment, when appropriate, recognizing that time-to-treatment is consistently associated with poorer long-term outcomes in a retrospective case series of autoimmune encephalitis patients. ${ }^{411,43,44}$ This recommendation also acknowledges the need to screen for other disease-associated autoantibodies that may account for the clinical presentation, including autoantibodies that are optimally detected in serum (e.g., leucine-rich glioma-inactivated protein 1 or contactinassociated protein 2 autoantibodies ${ }^{45,46}$ ).

This study is subject to several limitations. Although the patients included in this study were prospectively enrolled and longitudinally followed, study protocols did not include banking of serum. Thus, it was not possible to evaluate additional aliquots of serum from enrolled patients using other methods or techniques at other centers. We acknowledge that local test results may have accurately reflected patient serum antibody status ("true negative"). This finding is supported by the lack of autoantibody detection on selected samples that were also evaluated at a reference laboratory (i.e., patients 4, 5, and 7). Indeed, persistently seronegative cases of anti-NMDAR encephalitis are well recognized, ${ }^{47,48}$ suggesting that patient- and/or disease-specific factors may influence the detection of NMDAR IgG autoantibodies in serum. It is also plausible that further testing on serum samples utilizing additional techniques (e.g., immunohistochemistry, live cell-based assays ${ }^{7}$ ) may have identified NMDAR IgG autoantibodies at clinically relevant levels (in which case our findings would be regarded as "false negatives"). Future studies are needed to systematically evaluate the effect of preanalytic variation in sample collection, handling, and processing on serum antibody detection. It is particularly imperative that these studies bank serum and CSF samples from patients with definite anti-NMDAR encephalitis, permitting samples to be evaluated using more than one analytic method, in more than one environment (local/regional and research/academic laboratories). The findings presented here may be used to justify the effort and investment required to facilitate such rigorous follow-up studies in larger numbers of patients.

\section{Conclusions}

Commercial kits are available that allow NMDAR IgG autoantibodies to be measured in local laboratories. However, analysis of paired CSF and serum samples from patients with definite anti-NMDAR encephalitis presenting to our center suggests that commercial kits run according to manufacturer's specifications in exemplar clinical laboratories may yield lowerthan-expected rates of NMDAR IgG autoantibody detection in serum. Testing within local/regional laboratories and the use of single test modalities associated with reduced odds of serum NMDAR IgG autoantibody detection in the extant literature. These findings emphasize the need for caution when interpreting serum NMDAR IgG autoantibody test results and the need for future studies evaluating the factors that influence autoantibody detection rates across centers. Clinicians should continue to prioritize testing for NMDAR IgG autoantibodies in CSF from patients with suspected anti-NMDAR encephalitis.

\section{ACKnowledgments}

The authors thank Dr. Ann Gronowski for helpful comments concerning an earlier version of this work. The authors remain grateful to the patients and family members who made this work possible.

\section{FUNDING}

This study was made possible by support from the American Brain Foundation (Clinical Research Training Fellowship, GSD).

\section{CONFLict OF InTEREST}

Dr. JB is supported by fellowship funding from the Canadian Network of MS Clinics (including support from Biogen Idec Canada, EMD Serono, Sanofi Genzyme, Novartis Pharmaceuticals Canada Inc., Hoffmann-La Roche and Teva Canada Innovation). Dr. MLY declares no conflicts of interest. Dr. RCB receives an annual gift from a patient's family for Parsonage-Turner research, has served on an advisory board for MT Pharma, and has equity in Neuroquestions, LLC. Dr. GSD is supported by funding from the NIH/NIA (K23AG064029), is involved in research supported by an in-kind gift of radiopharmaceuticals from Avid Radiopharmaceuticals, serves as a topic editor for DynaMED (EBSCO Health), and holds stocks $(>\$ 10,000)$ in ANI Pharmaceuticals (a generic pharmaceutical company). Dr. GSD serves as the clinical director of the Anti-NMDA Receptor Encephalitis Foundation (no compensation provided); the Foundation is supported by private donations.

\section{Statement of Authorship}

Conceptualization, methodology: GSD, JAB. Writing, first draft: JAB. Writing, subsequent drafts and revision: JAB, GSD, MLY, RCB; Supervision: GSD

\section{SUPPLEMENTARY MATERIAL}

To view supplementary material for this article, please visit https://doi.org/10.1017/cjn.2019.305

\section{REFERENCES}

1. Dalmau J, Tuzun E, Wu HY, et al. Paraneoplastic anti- $N$-methyl-Daspartate receptor encephalitis associated with ovarian teratoma. Ann Neurol. 2007;61(1):25-36.

2. Fischer CE, Golas AC, Schweizer TA, et al. Anti $N$-methyl-Daspartate receptor encephalitis: a game-changer? Expert Rev Neurother. 2016;16(7):849-59.

3. Byrne S, Walsh C, Hacohen Y, et al. Earlier treatment of NMDAR antibody encephalitis in children results in a better outcome. Neurol Neuroimmunol Neuroinflamm. 2015;2(4):e130.

4. Titulaer MJ, McCracken L, Gabilondo I, et al. Treatment and prognostic factors for long-term outcome in patients with antiNMDA receptor encephalitis: an observational cohort study. Lancet Neurol. 2013;12(2):157-65.

5. Graus F, Titulaer MJ, Balu R, et al. A clinical approach to diagnosis of autoimmune encephalitis. Lancet Neurol. 2016;15(4):391-404. 
6. Hara M, Martinez-Hernandez E, Arino $\mathrm{H}$, et al. Clinical and pathogenic significance of $\operatorname{IgG}, \operatorname{IgA}$, and $\operatorname{IgM}$ antibodies against the NMDA receptor. Neurology. 2018;90(16):e1386-94.

7. Gresa-Arribas N, Titulaer MJ, Torrents A, et al. Antibody titres at diagnosis and during follow-up of anti-NMDA receptor encephalitis: a retrospective study. The Lancet Neurology. 2014;13(2):167-77.

8. Remy KE, Custer JW, Cappell J, et al. Pediatric anti- $N$-methyl-Daspartate receptor encephalitis: a review with pooled analysis and critical care emphasis. Front Pediatr. 2017;5:250.

9. Lennox BR, Palmer-Cooper EC, Pollak T, et al. Prevalence and clinical characteristics of serum neuronal cell surface antibodies in first-episode psychosis: a case-control study. Lancet Psychiatry 2017;4(1):42-8.

10. Euroimmun. Anti-Glutamate receptor (type NMDA) IFA Test Instruction (package insert). Version: 4/12/2017. Lubeck, Germany: Euroimmun AG.

11. Dalmau J, Gleichman AJ, Hughes EG, et al. Anti-NMDA-receptor encephalitis: case series and analysis of the effects of antibodies. Lancet Neurol. 2008;7(12):1091-8.

12. Lab S. SIR - SCImago Institutional Rankings; 2019. Accessed August 202019.

13. Gronseth GS, Cox J, Gloss D, et al. Clinical Practice Guideline Process Manual Minneapolis; 2017. Minneapolis, MN: The American Academy of Neurology.

14. Higgins JP, Thompson SG, Deeks JJ, Altman DG. Measuring inconsistency in meta-analyses. BMJ. 2003;327(7414):557-60.

15. Higgins JP, Thompson SG. Quantifying heterogeneity in a metaanalysis. Stat Med. 2002;21(11):1539-58.

16. Maat P, De Graaff E, Van Beveren NM, et al. Psychiatric phenomena as initial manifestation of encephalitis by anti-NMDAR antibodies. Acta Neuropsychiatr. 2013;25(3):128-36.

17. Suhs KW, Wegner F, Skripuletz T, et al. Heterogeneity of clinical features and corresponding antibodies in seven patients with anti-NMDA receptor encephalitis. Exp Ther Med. 2015;10(4): 1283-92.

18. Kelleher E, McNamara P, Fitzmaurice B, et al. Prevalence rate of $N$-methyl-D-aspartate (NMDA) receptor antibodies in first episode psychosis. Eur Psychiatr. 2015;30(Suppl 1):1568.

19. Wang R, Guan HZ, Ren HT, Wang W, Hong Z, Zhou D. CSF findings in patients with anti- $N$-methyl-D-aspartate receptorencephalitis. Seizure 2015;29:137-42.

20. Saito M, Suzuki Y, Kikuchi Y, et al. Differences between auto-antibody titres in cerebrospinal fluids and sera of patients with anti- $N$-methyl-D receptor encephalitis. Schizophr Bull. 2017;43(Suppl 1):S67-8.

21. Aungsumart S, Ha A, Apiwattanakul M. Abnormal level of consciousness predicts outcomes of patients with anti-NMDA encephalitis. J Clin Neurosci. 2019;62:184-7.

22. Ding YW, Pan SY, Xie W, Shen HY, Wang HH. Elevated soluble Fas and FasL in cerebrospinal fluid and serum of patients with anti- $N$-methyl-D-aspartate receptor encephalitis. Front Neurol. 2018;9(OCT).

23. Mahadevan A, Nagappa M, Bindu PS, et al. Utility of an advanced diagnostic facility for autoimmune neurological and neuropsychiatric disorders at neuromuscular lab at NIMHANS. Ann Indian Acad Neurol. 2016;19(6):S119.

24. Kataoka H, Sawa N, Tonomura Y, Ueno S. Early progression of brain atrophy in patients with anti- $N$-methyl-D-Aspartate receptor encephalitis. Medicine (United States) 2017;96(17):e6776.

25. Gastaldi M, Thouin A, Coutinho EP, Jacobson L, Irani S, Vincent AC. Comparison of antibody assays in anti-NMDAR encephalitis. Eur J Neurol. 2016;23(Suppl 2):577.

26. Zandi MS, Paterson RW, Ellul MA, et al. Clinical relevance of serum antibodies to extracellular $N$-methyl-D-aspartate receptor epitopes. J Neurol Neurosurg Psychiatr. 2015;86(7):708-13.

27. Alexopoulos H, Akrivou S, Mastroyanni S, et al. Postherpes simplex encephalitis: a case series of viral-triggered autoimmunity, synaptic autoantibodies and response to therapy. Ther Adv Neurol Disord. 2018;11.
28. Barros P, Brito H, Ferreira PC, et al. Resective surgery in the treatment of super-refractory partial status epilepticus secondary to NMDAR antibody encephalitis. Eur J Paediatr Neurol. 2014;18(3):449-52.

29. Fauzi NAM, Joseph JP, Zain NRM, Hashim H. A severe anti-NMDA-receptor encephalitis case with extensive cortical and white matter changes, cerebral atrophy and communicating hydrocephalus. Proc Singapore Healthcare. 2017;26(1):58-61.

30. Zhou J, Tan W, Tan SE, Hu J, Chen Z, Wang K. An unusual case of anti-MOG CNS demyelination with concomitant mild anti-NMDAR encephalitis. J Neuroimmunol. 2018;320:107-10.

31. Orengo JP, Pekmezci M, Cree BA. Simultaneous serum aquaporin-4 antibody and CSF NMDA receptor antibody-positive encephalitis. Neurol Neuroimmunol Neuroinflamm. 2015;2(3):e101.

32. Guan HZ, Ren HT, Yang XZ, et al. Limbic encephalitis associated with anti-gamma-aminobutyric acid $\mathrm{B}$ receptor antibodies: a case series from China. Chin Med J (Engl). 2015;128(22):3023-8.

33. Irani SR, Bera $\mathrm{K}$, Waters $\mathrm{P}$, et al. $N$-methyl-D-aspartate antibody encephalitis: temporal progression of clinical and paraclinical observations in a predominantly non-paraneoplastic disorder of both sexes. Brain 2010;133(Pt 6):1655-67.

34. Scott JG, Gillis D, Ryan AE, et al. The prevalence and treatment outcomes of antineuronal antibody-positive patients admitted with first episode of psychosis. BJPsych Open. 2018;4(2):69-74.

35. Bergink V, Armangue T, Titulaer MJ, Markx S, Dalmau J, Kushner SA. Autoimmune encephalitis in postpartum psychosis. Am J Psychiatr. 2015;172(9):901-8.

36. Doden T, Sekijima Y, Ikeda J, et al. Postpartum anti- $N$-methyl-Daspartate receptor encephalitis: a case report and literature review. Intern Med. 2017;56(3):357-62.

37. Kayser MS, Titulaer MJ, Gresa-Arribas N, Dalmau J. Frequency and characteristics of isolated psychiatric episodes in anti- $N$-methyl-D-aspartate receptor encephalitis. JAMA Neurol. 2013;70(9):1133-9.

38. DeSena AD, Greenberg BM, Graves D. "Light switch" mental status changes and irritable insomnia are two particularly salient features of anti-NMDA receptor antibody encephalitis. Pediatr Neurol. 2014;51(1):151-3.

39. Mechelhoff D, van Noort BM, Weschke B, et al. Anti-NMDA receptor encephalitis presenting as atypical anorexia nervosa: an adolescent case report. Eur Child Adolesc Psychiatr. 2015;24(11):1321-4.

40. Marques IB, Teotonio R, Cunha C, Bento C, Sales F. Anti-NMDA receptor encephalitis presenting with total insomnia-a case report. J Neurol Sci. 2014;336(1-2):276-80.

41. Lejuste F, Thomas L, Picard G, et al. Neuroleptic intolerance in patients with anti-NMDAR encephalitis. Neurol Neuroimmunol Neuroinflamm. 2016;3(5):e280.

42. Berg A, Byrne R, Coffey BJ. Neuroleptic malignant syndrome in a boy with NMDA receptor encephalitis. J Child Adolesc Psychopharmacol. 2015;25(4):368-71.

43. Finke C, Pruss H, Heine J, et al. Evaluation of cognitive deficits and structural hippocampal damage in encephalitis with leucine-rich, glioma-inactivated 1 antibodies. JAMA Neurol. 2017;74(1):50-9.

44. Hebert J, Day GS, Steriade C, Wennberg RA, Tang-Wai DF. Long-term cognitive outcomes in patients with autoimmune encephalitis. Can J Neurol Sci. 2018:1-5.

45. Kim TJ, Lee ST, Moon J, et al. Anti-LGI1 encephalitis is associated with unique HLA subtypes. Ann Neurol. 2017;81(2): 183-92.

46. van Sonderen A, Roelen DL, Stoop JA, et al. Anti-LGI1 encephalitis is strongly associated with HLA-DR7 and HLA-DRB4. Ann Neurol. 2017;81(2):193-8.

47. Frechette ES, Zhou L, Galetta SL, Chen L, Dalmau J. Prolonged follow-up and CSF antibody titers in a patient with anti-NMDA receptor encephalitis. Neurology 2011;76(7 Suppl 2):S64-6.

48. Kruer MC, Koch TK, Bourdette DN, et al. NMDA receptor encephalitis mimicking seronegative neuromyelitis optica. Neurology 2010;74(18):1473-5. 